Brit. F. vener. Dis. (1967), 43, 81.

\title{
ARTHRITIS AND GENITAL INFECTION IN PARAPLEGIC PATIENTS*
}

\author{
BY \\ R. D. CATTERALL, V. WRIGHT, AND J. B. COOK \\ From the Middlesex Hospital, London, W.1, the General Infirmary at Leeds, and \\ Pinderfields Hospital, Wakefield, Yorks
}

In recent years there has been considerable discussion about the importance of chronic genitourinary infection as a cause of disease of the sacro-iliac joints. Mason, Murray, Oates, and Young (1958) demonstrated that there was a high incidence of chronic prostato-vesiculitis in patients with ankylosing spondylitis. Several observers have found an increased incidence of sacro-iliitis in patients with Reiter's disease (Ford, 1953; Stanworth and Sharp, 1956; Murray, Oates, and Young, 1958; Reynolds and Csonka, 1958; Wright, 1963). A suggestion was put forward that infection might spread by way of the venous system which links the prostate and seminal vesicles with the sacro-iliac joints (Batson, 1942; Grainger, 1959). The possibility that ankylosing spondylitis might be caused by chronic genito-urinary infection has been discussed by several observers (Romanus, 1953; Catterall, 1961).

Further evidence in favour of this hypothesis has been brought forward and includes the view that a similar type of sacro-iliitis occurs in patients with paraplegia (Abel, 1950; Lodge, 1956). Mason and others (1958), in a review of the available facts, were of the opinion that chronic genitourinary inflammation was a possible cause of sacro-iliac disease and cited the high incidence of sacro-iliac abnormalities in men with paraplegia, the majority of whom might be expected to have chronic genito-urinary infection, in support of this idea. A leading article in the British Medical fournal (1960) put forward arguments along similar lines.

There have only been a few detailed investigations into the bone and joint changes in paraplegic patients. The majority of the studies have been retrospective and little or no attempt has been made to correlate the clinical findings. Osteoporosis

* Received for publication July 25, 1966. and soft tissue calcification have been described, but there are few references to the peripheral joints or bones.

The largest radiological study was carried out by Lodge (1956). The radiological films of 236 patients were reviewed and osteoporosis was found in 127 of them. Ectopic calcification was present in 33 per cent., usually between the pelvis and the knees, and frequently round the hips. Miller and O'Neill (1949) found soft tissue calcification in several patients and stated that it never occurred above the pelvis or below the knees, but was frequent in the area of the medial femoral condyle. Abramson and Kamberg (1949) investigated 35 cases and found osteoporosis in six and proliferative bone changes and soft tissue calcification about the hips and upper portion of the femur in seven patients. Erosion of bone over pressure points, particularly the sacrum, the greater trochanter, and the ischial tuberosities was noted by Heilbrun and Kuhn (1947). Changes resembling Charcot's arthropathy in paraplegic patients were described by Brailsford (1941).

\section{Present Investigation}

This prospective investigation was carried out to try to determine the nature of the bone and joint changes in patients with paraplegia. An attempt was also made to investigate the patients for evidence of genito-urinary infection and to see whether there was any correlation between the two groups of findings. Detailed clinical, radiological, serological, and bacteriological examinations were carried out on each patient and special attention was paid to the sacro-iliac joints.

\section{Material and Method}

38 men who were patients at the Paraplegic Unit at Pinderfields Hospital, Wakefield, were investigated. The majority of the patients had been sent home from 
the Unit and were under regular surveillance as outpatients. Some had been readmitted for the treatment of decubitus ulcers and the series therefore contains a relatively large number of patients with ulcers.

All the patients were examined clinically and an assessment of the type and extent of the paraplegia was made, the joints were examined in detail and the genito-urinary tract was investigated thoroughly. Cystoscopy was performed where indicated.

Radiographs of the feet and sacro-iliac joints were taken in all patients and radiographs of the spine in the majority of instances. The serum albumin and globulin, the serum uric acid, the blood urea, and the Rose-Waaler differential sheep cell agglutination test were carried out in all cases. An early morning urethral smear and culture were taken from all patients and culture media for growing Trichomonas vaginalis were inoculated. In a number of patients digital examination of the prostate was carried out and prostatic massage performed. Specimens of prostatic fluid were examined microscopically in a wet preparation, a Gram-stained slide, and by culture. The urine was examined by the two-glass test wherever possible and for protein and sugar. The centrifuged deposit of a sample of the urine was examined microscopically and by culture in every case. Intravenous pyelography was performed in a number of patients and cystoscopy in selected cases.

The radiographs were assessed by two observers without knowledge of the clinical history and findings. Special attention was directed to sclerosis, erosion, and ankylosis of the sacro-iliac joints. Films of the feet were also carefully assessed for evidence of osteoporosis and the findings were graded as follows: $0=$ no change; $1=$ doubtful ; 2 =mild; $3=$ moderate; $4=$ severe. The changes were also described as generalized or patchy. Films of the spine were also examined for evidence of spondylitis. Calcification of the soft tissue was looked for on all the films.

\section{Findings}

The ages of the 38 men ranged from 9 to 64 years (mean $38 \cdot 1$ ). In 33 patients the paraplegia was due to injury, frequently occurring in a coal mine but due to road accidents in some. Of the other five, one had multiple sclerosis, one sub-acute combined degeneration of the cord, one an angioma of the lower part of the spinal cord, and one Paget's disease. In the fifth patient the cause of the paraplegia was not apparent and at laminectomy thickening of the dura mater with surrounding granulation tissue suggesting pachymeningitis was found in the region of the third dorsal vertebra (Table I).

Paraplegia was complete in 24 and partial in fourteen patients. It was predominantly motor in six, mainly sensory in two, and combined in thirty. It was of long duration in seventeen patients, having been present for between 3 and 5 years in nine and from 6 to 10 years in eight. Eight patients had been paralysed for 1 to 2 years, six for 6 to 12 months, and seven for less than 6 months. The level of the lesions was variable. In four cases it was in the cervical region, in eighteen
TABLE I

CAUSE OF PARAPLEGIA

\begin{tabular}{|c|c|c|c|c|}
\hline \multicolumn{4}{|c|}{ Diagnosis } & No. of Cases \\
\hline $\begin{array}{l}\text { Trauma .. } \\
\text { Disseminated sclerosis } \\
\text { Paget's disease } \\
\text { Sub-acute combined de } \\
\text { Angioma of spinal cord } \\
\text { Pachymeningitis }\end{array}$ & 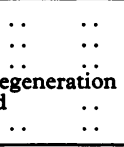 & $\begin{array}{l}\cdots \\
\ddot{ } \\
\cdots \\
\cdots\end{array}$ & $\begin{array}{l}\cdots \\
\cdots \\
\cdots \\
\cdots\end{array}$ & $\begin{array}{r}33 \\
1 \\
1 \\
1 \\
1 \\
1\end{array}$ \\
\hline Total & . & . & . & 38 \\
\hline
\end{tabular}

in the dorsal region, in five in the dorso-lumbar region, and in eleven in the region of the cauda equina.

The majority of the patients were admitted to the special paraplegic unit immediately, but in eleven cases there was delay in admission with consequent delay in mobilization.

Decubitus ulcers (Fig. 1) were present in the sacral area in seventeen patients, over the hip in nine, around the ankle in four, and in other sites such as the elbow, heel, and big toe in five. Severe ulceration was most frequent amongst patients confined to bed for long periods. Ulcers were present in all patients who had been in bed for over 7 months, in 80 per cent. of those in bed for 4 to 6 months, and only in 20 per cent. of those who were up within 3 months. There was no relationship between ulceration and the age of the patient, nor did the level of the cord lesion influence the incidence of ulcers. They were, however, three times as common in patients with both motor and sensory damage as in those with either motor or sensory damage alone.

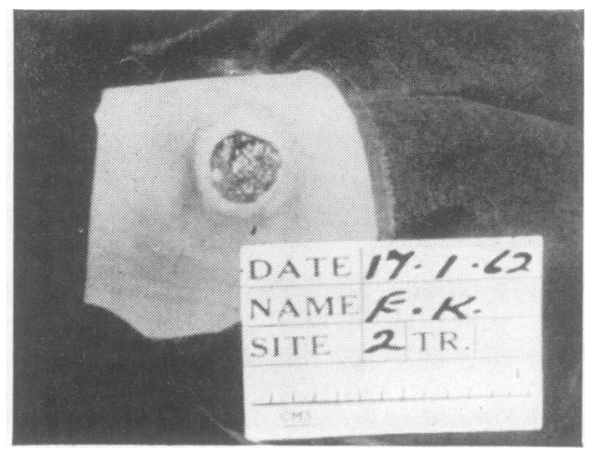

FIG. 1.-Moderate decubitus ulceration over greater trochanter.

Permanent contractures were rare; they occurred in only three patients and were severe in two and mild in one of them. Loss of weight occurred in over half the patients and six showed a loss of over 20 per cent. of their original body weight.

\section{Genito-urinary Findings}

Some abnormality of micturition had been present in all the patients. They had all needed catheterization 
at some stage of the illness and urinary infection had occurred in all of them. Suprapubic drainage had been required in only one.

At the time of examination, urinary infection, as measured by the two-glass urine test and microscopical and cultural tests of a centrifuged deposit of urine, was present in 25 patients.

An attempt to discover the presence of chronic genital infection was made in all the patients by examination of an early morning smear and culture and by examination of specimens of the prostatic secretions in 24 patients. It was not always possible to perform prostatic massage owing to great difficulties in positioning the paraplegic patients, and to reflex micturition and defaecation, which occurred in many of the patients when this procedure was attempted. In a small number of patients a type of "mass-reflex" occurred when prostatic massage was attempted, with involuntary flexion of the legs, penile erection and occasionally ejaculation, involuntary micturition and defaecation, and considerable discomfort to the patient.

The degree of infection of the genital tract was assessed by the number of pus cells in the urethral smear and the number of pus cells and clumps of pus in the prostatic secretions. It was absent in twelve patients, very mild in fourteen, moderately severe in nine, and severe in three.

Culture of the urethral and prostatic secretions showed no growth of organisms in nine patients, streptococci in five, staphylococci in twelve, diphtheroids in eleven, and coliform organisms in seven. Nonpathogenic Neisseria was grown in seven, anthracoids in four, and $B$. proteus in two.

Cystoscopy was performed on seventeen patients and bladder calculi were found in six.

\section{Bone and Articular Manifestations}

Careful examination of the peripheral joints revealed Heberden's nodes in two patients, pain and stiffness in the right shoulder in four, swelling of the knee in two, and contractures in three. Restriction of ankle movements occurred in the majority of patients and was severe in fifteen.

The sacro-iliac joints were affected in twelve patients (Table II).

TABLE II

JOINT CHANGES IN PARAPLEGIA

\begin{tabular}{|c|c|c|c|c|}
\hline \multicolumn{4}{|c|}{ Joint Changes } & $\begin{array}{c}\text { No. of } \\
\text { Cases }\end{array}$ \\
\hline \multirow{4}{*}{ Peripheral } & Heberden's nod & .. & $\ldots$ & 2 \\
\hline & Right shoulder & \multicolumn{2}{|c|}{$\begin{array}{l}\text { Pain .. } \\
\text { Recurrent dislocation }\end{array}$} & $\begin{array}{l}4 \\
1\end{array}$ \\
\hline & Knee .. .. & $\begin{array}{l}\text { Swelling } \\
\text { Warmth } \\
\text { Contractures }\end{array}$ & $\begin{array}{l}\cdots \\
\cdots \\
\cdots\end{array}$ & $\begin{array}{l}2 \\
1 \\
3\end{array}$ \\
\hline & \multicolumn{2}{|c|}{ Ankle, severe restriction } & $\cdots$ & 15 \\
\hline Sacro-iliac & $\cdots$ & $\ldots$ & $\cdots$ & 12 \\
\hline
\end{tabular}

Osteoporosis of the feet occurred in 23 patients, being generalized in eight and patchy in fifteen. Of six patients with paraplegia of less than 6 months duration, only one showed moderate osteoporosis of the feet, one showed no osteoporosis, and in the other four it was mild. Of the 29 patients with paraplegia of longer than 6 months duration, fourteen (48 per cent.) had pronounced osteoporosis. The incidence was 52 per cent. in those with paraplegia of 7 months to 2 years duration and 43 per cent. in those with paraplegia of over 2 years duration. It seemed that pronounced osteoporosis developed soon after the sixth month and that there was little change in the condition afterwards. Osteoporosis was not related to age. It was pronounced in three of ten patients less than 25 years old compared with only three of twelve patients over 45 years of age (Figs 2 and 3).

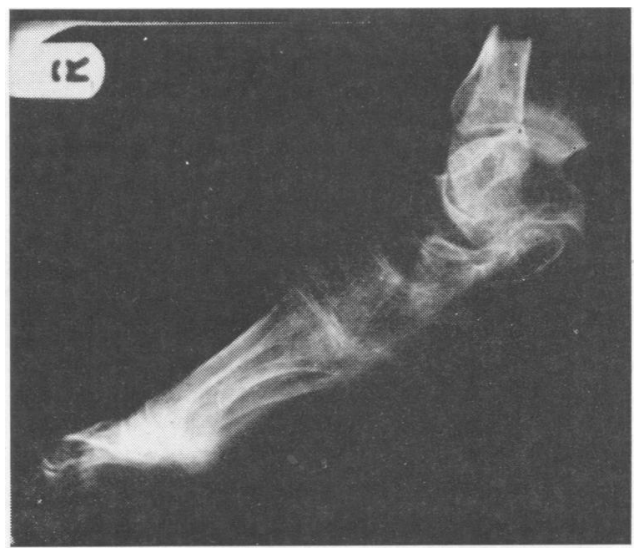

FIG. 2.-Generalized osteoporosis shown on lateral radiograph of foot.

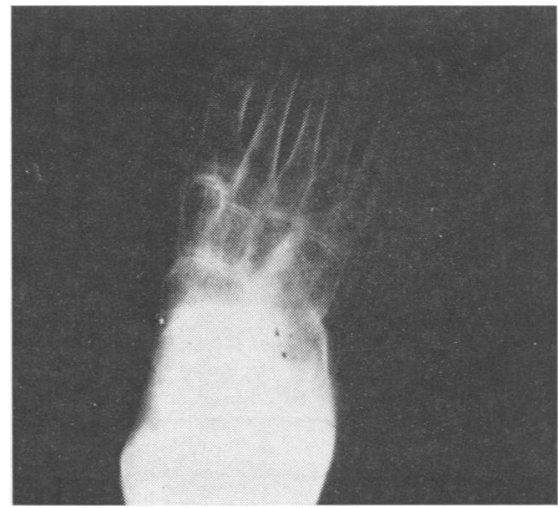

FIG. 3.-Severe generalized osteoporosis of foot. 
There was evidence that the longer the patient was in bed the greater was the frequency of osteoporosis (Table III). There was also some suggestion that osteoporosis was correlated with persistant oedema, which was found in eleven patients.

TABLE III

BONE CHANGES IN PARAPLEGIA

\begin{tabular}{|c|c|c|c|c|c|}
\hline \multicolumn{5}{|c|}{ Bone Changes } & No. of Cases \\
\hline $\begin{array}{c}\text { Clubbing } \\
\text { Fingers } \\
\text { Toes }\end{array}$ & $\begin{array}{l}\cdots \\
\cdots\end{array}$ & $\begin{array}{l}\cdots \\
\cdots \\
\cdots\end{array}$ & $\begin{array}{l}\cdots \\
\cdots \\
\cdots\end{array}$ & $\begin{array}{l}\cdots \\
\cdots \\
\cdots\end{array}$ & $\begin{array}{r}11 \\
4 \\
8\end{array}$ \\
\hline $\begin{array}{l}\text { Osteoporosis } \\
\text { Generalized } \\
\text { Patchy }\end{array}$ & & $\begin{array}{l}\ddot{ } \\
\ddot{*}\end{array}$ & $\begin{array}{l}\cdots \\
\cdots\end{array}$ & $\begin{array}{l}\cdots \\
\cdots \\
\cdots\end{array}$ & $\begin{array}{c}23 \text { (of } 35 \text { ) } \\
8 \\
15\end{array}$ \\
\hline Calcification & $\ldots$ & $\ldots$ & .. & . & 2 \\
\hline
\end{tabular}

Clubbing of the digits was discovered in eleven patients (Table III). Four had clubbing of the fingers and eight clubbing of the toes. Erythema around the base of the nails was present in these patients and was marked in five of them. Clubbing was not found in any of the thirteen patients with paraplegia of less than 1 year's duration. It occurred in 44 per cent. of those with paraplegia of longer duration (Table IV).

\section{TABLE IV}

CLUBBING RELATED TO DURATION OF PARAPLEGIA

\begin{tabular}{c|c}
\hline Duration (yrs) & $\begin{array}{c}\text { Incidence of Clubbing } \\
\text { (per cent.) }\end{array}$ \\
\hline 1 & 0 \\
1 & 44 \\
$1-2$ & 50 \\
$3-5$ & 44 \\
$6-10$ & 38 \\
\hline
\end{tabular}

It was also more frequent in those with significant decubitus ulcers ( 8 of 13) as compared with those with minor or no ulceration ( 3 of 25) (Table V). Clubbing was twice as common when persistent oedema occurred ( 5 of 11) as in those without oedema (6 of 27) (Table VI). There was no correlation with the level of the spinal cord lesion and none with genito-urinary infection.

TABLE V

CLUBBING RELATED TO DECUBITUS ULCERS IN PARAPLEGIA

\begin{tabular}{|c|c|}
\hline Ulceration & Incidence of Clubbing \\
\hline $\begin{array}{lll}\begin{array}{l}\text { Pronounced } \\
\text { Mild or absent }\end{array} & \ldots & \ldots\end{array}$ & $\begin{array}{l}61 \text { per cent. }(8 / 13) \\
12 \text { per cent. }(3 / 25)\end{array}$ \\
\hline
\end{tabular}

TABLE VI

CLUBBING RELATED TO PERSISTENT OEDEMA IN PARAPLEGIA

\begin{tabular}{|c|c|c|c|c|}
\hline \multicolumn{4}{|c|}{ Oedema } & Incidence of Clubbing \\
\hline $\begin{array}{l}\text { Persistent } \\
\text { Absent .. }\end{array}$ & 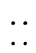 & 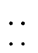 & 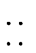 & $\begin{array}{l}46 \text { per cent. }(5 / 11) \\
22 \text { per cent. }(6 / 27)\end{array}$ \\
\hline
\end{tabular}

Sacro-iliac joint changes were seen radiologically in twelve patients. It was very striking that these changes were quite different from those occurring in ankylosing spondylitis, Reiter's disease, or ulcerative colitis. There were no major erosions of the joints and no patient showed complete ankylosis of the joints. None of the radiographs showed moderate or severe sacro-iliitis as depicted by the "Atlas of Standard Radiographs".

Five patients with sacro-iliac changes were under 35 years of age and seven were between 36 and 65 years. The relationship of sacro-iliac changes to the duration of paraplegia showed that 23 per cent. of those with paraplegia of less than 12 months duration had changes compared with 36 per cent. of those of more than 12 months duration. There was, therefore, little difference in incidence amongst those with paraplegia of short duration as compared with those of the longest duration. One patient with paraplegia of less than 3 months duration had sacro-iliac changes.

There was a marked increase in the incidence of sacro-iliac changes when admission to the special paraplegia unit had been delayed. In addition, two of the three bedfast patients had sacro-iliac changes. More detailed analysis showed that there was a marked increase in sacro-iliac changes in those patients in whom full mobilization had been delayed (Fig. 4, and Figs 5 and 6, opposite).

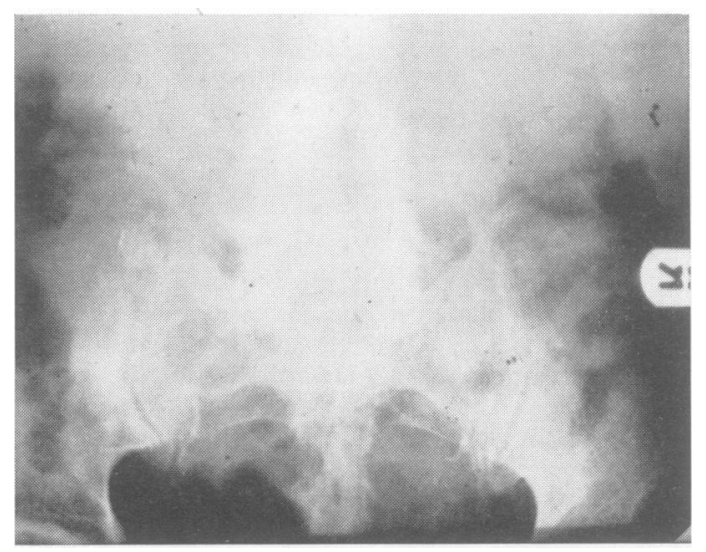

FIc. 4.-Sacro-iliac joint charges.

Sacro-iliac changes were not related to the presence or severity of genital infection as assessed by early morning smear and culture and examination of the prostatic secretions. In fact the incidence of sacro-iliac changes was higher in those without infection (58 per cent.) than in those with infection (19 per cent.).

When the two-glass test and examination of the centrifuged deposit of urine was used to assess urinary tract infection, it was found that 24 per cent. of the 25 patients with infection had sacro-iliac changes as compared with 46 per cent. of thirteen patients without infection. There was no relationship between sacro-iliac changes and the organisms cultured from the urethra, 


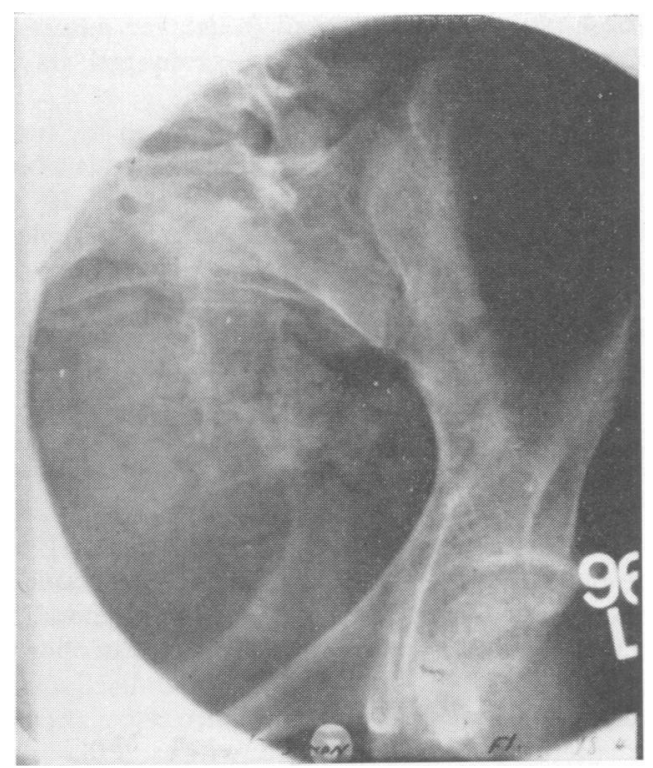

FIG. 5.-Oblique view of sacro-iliac joint changes.

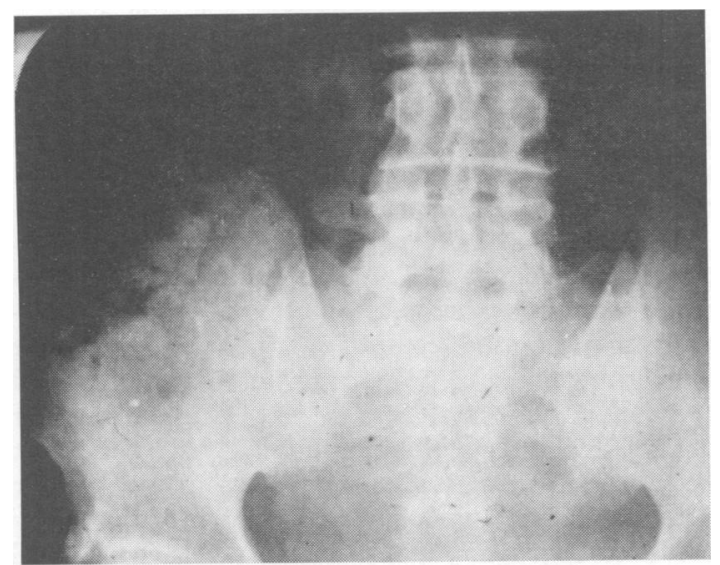

Fig. 6.-Sacro-iliac joint changes.

prostate, or bladder, or to the presence of bladder calculi.

Sacro-iliac changes were not related to the presence or the situation of skin ulceration and there was no relationship between sacro-iliac changes and clubbing, contractures, weight loss, or restriction of ankle movement. Radiographs of the lumbar spine were available in 26 patients. None of them showed evidence of spondylitis or of ligamentous calcification.

\section{Blood Investigations}

Two patients had positive differential sheep cell agglutination tests at titres of 1 in 16 and 1 in 256 . The blood urea was elevated to $46 \mathrm{mg} . / 100 \mathrm{ml}$. in only one patient. Serum uric acid levels were normal except in one patient, in whom it was $10 \mathrm{mg} .100 \mathrm{ml}$. On the other hand, the serum globulin was raised in ten of the patients (Table VII).

TABLE VII

ABNORMAL BLOOD TESTS IN PARAPLEGIA

\begin{tabular}{|c|c|c|c|c|}
\hline \multicolumn{3}{|c|}{ Test } & $\begin{array}{l}\text { No. } \\
\text { Abnormal }\end{array}$ & Result \\
\hline \multicolumn{3}{|c|}{$\begin{array}{l}\text { Differential Sheep Cell } \\
\text { Agglutination Test }\end{array}$} & 2 & 16 \\
\hline Urea $\quad \ldots$ & $\ldots$ & $\cdots$ & 1 & $46 \mathrm{mg} . / 100 \mathrm{ml}$ \\
\hline Uric acid & . & $\ldots$ & 1 & $10.0 \mathrm{mg} . / 100 \mathrm{ml}$ \\
\hline Globulin & & $\ldots$ & 10 & $\begin{array}{l}4 \cdot 0,4 \cdot 6,3 \cdot 4,3 \cdot 4, \\
4 \cdot 9,3 \cdot 3,4 \cdot 3,4 \cdot 4, \\
3 \cdot 4,3 \cdot 8(\mathrm{~g} \cdot / 100 \mathrm{ml})\end{array}$ \\
\hline
\end{tabular}

\section{Discussion}

Relatively little work on the bone and joint changes in paraplegia has been published and they are not mentioned in the two leading text-books on the rheumatic diseases (Hollander, 1960; Copeman, 1964). The majority of the observations have been retrospective and have concerned the radiological changes in the joints and soft tissues.

Other complications of paraplegia are well known and include decubitis ulcers and persistent oedema. In our series ulceration was found most commonly over the sacrum and hips. It was present most frequently in those confined to bed for the longest periods and in those with both motor and sensory neurological impairment. Oedema was persistent in eleven patients. This may have been connected with deep venous thrombosis as this is known to be a common complication of paraplegia (Philipps, 1963) and, in a recent series of sixteen patients who died within 2 months of the onset of paraplegia, Tribe (1963) found that six had suffered pulmonary embolism.

There has been considerable interest in the past in the sacro-iliac joint changes found in paraplegia and in their relationship to other types of sacro-iliac disease. Abel (1950) reported sacro-iliac joint changes in 61 per cent. of his group of patients. Abramson and Kamberg (1949) considered that there was a similarity in the joint changes to those of ankylosing spondylitis. However, on reviewing the radiographs in these papers, there is considerable doubt whether the sacro-iliac joint changes are the same as those occurring in ankylosing spondylitis or in sacro-iliitis associated with Reiter's disease or ulcerative colitis.

In this investigation the radiographs showed no major erosive changes and in no case was there complete ankylosis of the sacro-iliac joints. We 
formed the very strong impression that the changes observed are distinct and different from those of ankylosing spondylitis and Reiter's disease. The term "sacro-iliitis" has been deliberately avoided and "sacro-iliac joint changes" has been used so as not to prejudge the issue. The changes found in this study are probably due to the severe mechanical stresses to which the pelvis is subjected in paraplegic patients, acting on osteoporotic bone. The patients sit and lie upon unsupported bones and joints, and when they are mobilized, often with the use of crutches, the pelvis is unprotected from various types of abnormal mechanical strains.

Some support for this suggestion comes from a biopsy study carried out on the sacro-iliac joints on one patient by Abel (1950). There was no joint space and no cartilage, and the area of adjacent bone was very vascular and the cortex thin. Microscopically, the bone was very atrophic, there was no pannus and the appearances were those of atrophied cartilage. It is also interesting to note that Romanus (1953), in his monograph on ankylosing spondylitis, described sixteen patients with paraplegia, and had several reservations in deciding whether the changes he observed corresponded to those of ankylosing spondylitis.

In this investigation special attention was directed towards the genito-urinary tract to try to assess the incidence and severity of infection. Such investigations are not easy in paraplegic patients. Many are incontinent, some have an indwelling catheter, and others wear a portable urinal to collect the urine. Collection of specimens of prostatic secretion is also difficult and in some patients quite impossible. For these reasons full and complete evaluation of the condition of the genitourinary tract was not always possible but was carried out in over half the patients. In every case it was possible to make an assessment of possible genito-urinary infection, although this was not ideal in every case.

No correlation was found between the presence of genito-urinary infection and sacro-iliac changes. Nor was there any correlation between the type of infecting organism and joint changes. We could find no evidence from this study to support the hypothesis that sacro-iliitis or sacro-iliac joint changes occur as a result of chronic genito-urinary infection. However, the joint changes in paraplegia are different from those occurring in ankylosing spondylitis, Reiter's disease, and ulcerative collitis, and the sacro-iliac joint changes in those conditions could be due to chronic genito-urinary infection. This theory is not supported by the changes found in patients with paraplegia. Sacro-iliac joint changes in these patients were related to delayed admission to the special paraplegic units, prolonged stay in bed, and delayed mobilization.

The most significant clinical finding in the bones was clubbing. No previous reference to this observation could be found in the literature. In the eleven patients in whom it was found, the paraplegia had been present for over one year. Clubbing was more common in those with decubitus ulcers but was not related to the site of ulceration. There was a striking correlation between the presence of persistent oedema and clubbing.

Osteoporosis was found in all except one patient. In the past, attention has been confined to the pelvis and few observations have been made about the peripheral bones and joints (Lodge, 1956). Pronounced osteoporosis of the feet was found in two-thirds of our patients, and this was generalized in eight. It is probable that patchy osteoporosis occurs first and is followed by generalized osteoporosis. This suggestion is supported by the fact that there was a marked correlation between generalized osteoporosis and the duration of paraplegia. Pronounced osteoporosis was a good deal more frequent when the paraplegia had been present for 6 months, but there was little change in its incidence after this. It appears, therefore, that major osteoporosis develops at about 6 months after the onset of the paraplegia and does not become worse afterwards.

Osteoporosis occurred more frequently with persistent oedema and with clubbing. This correlation suggests the possibility that disuse osteoporosis may be the result of vascular changes. There is good evidence to believe that clubbing is related to vascular abnormalities (Flavell, 1956). From our observations it seems probable that persistent oedema is due to similar causes. None of the patients had a low serum albumin, there was no evidence of inflammatory changes, and the normal blood urea suggests that renal function was not severely impaired. The most probable explanation of the persistent oedema, therefore, is that it is of vascular origin.

The correlation between these two features and pronounced osteoporosis provides circumstantial evidence that the bone changes may have a vascular basis. Trueta (1964), from other evidence, came to the conclusion that disuse osteoporosis in other conditions was probably vascular in origin.

The persistent oedema in paraplegics may be due to the occurrence of deep venous thrombosis. This suggestion is supported by the work of Tribe (1963), who described death from pulmonary embolism due to deep vein thrombosis in a number 
of paraplegics, and the observations of Philipps (1963) who showed that venous thrombosis was more likely to occur in paraplegics than in the normal population. It is probable that this may have been the underlying vascular abnormality in our patients.

\section{Summary}

(1) 38 male patients with paraplegia were carefully studied. The paraplegia was due to injury in 33. It was complete in 24 and had been present for over 2 years in seventeen.

(2) The cord lesion was in the cervical region in four, in the dorsal region in eighteen, in the dorso-lumbar region in five, and in the cauda equina in eleven. Admission to a special paraplegic unit was delayed in eleven cases. Decubitus ulcers were present in 25, of which twelve were mild. The ulceration was related to delayed mobilization and occurred three times as frequently amongst patients who had both motor and sensory damage. Persistent oedema occurred in eleven patients. Permanent flexion contractures were present in three. Twenty patients had lost weight.

(3) Urinary infection was present in 25 patients, and chronic genital infection in 26 ; cystoscopy revealed bladder calculi in six.

(4) The most striking feature found in the bones was clubbing, which occurred in eleven patients. It did not occur in patients with paraplegia of less than 1 year's duration, was present more frequently with decubitus ulcers, and was twice as common when persistent oedema was present. Pronounced osteoporosis of the feet was found in 23 patients, being generalized in eight and patchy in fifteen. Calcification of the soft tissue was seen in two patients.

(5) Sacro-iliac joint changes were seen in twelve patients. These were different from the changes of sacro-iliitis which are seen in patients with ankylosing spondylitis, Reiter's disease, and ulcerative colitis. It is suggested that in cases of paraplegia these changes are due to mechanical stresses on osteoporotic bones surrounding the joint. There was no evidence to connect the sacro-iliac joint changes with chronic genito-urinary infection, nor with decubitus ulceration. Sacro-iliac joint changes were found more frequently in patients whose admission to hospital had been delayed, those who had been confined to bed for longer periods, and those in whom mobilization was delayed.

(6) Osteoporosis was present in patients with paraplegia of longer duration, in those confined to bed for long periods, in those with severe restriction of movement of the ankles, and in those with persistent oedema and clubbing of the digits.

(7) The evidence from this investigation suggests that osteoporosis, persistent oedema, and clubbing in patients with paraplegia may all be caused by vascular abnormalities.

\section{REFERENCES}

Abel, M. S. (1950). Radiology, 55, 235.

Abramson, D. J., and Kamberg, S. (1949). F. Bone $\mathcal{F t}$ Surg., 31-A, 275.

Batson, O. V. (1942). Ann. intern. Med., 16, 38.

Brailsford, J. F. (1941). Brit. F. Radiol., 14, 320.

Catterall, R. D. (1961). Lancet, 2, 739.

Copeman, W. S. C. (1964). "Textbook of the Rheumatic Diseases", 3rd ed. Livingstone, Edinburgh.

Flavell, G. (1956). Lancet, 1, 260.

Ford, D. K. (1953). Ann. rheum. Dis., 12, 177.

Grainger, R. G. (1959). F. Fac. Radiol. (Lond.), 10, 138.

Heilbrun, N., and Kuhn, W. G. (1947). Radiology, 48, 579.

Hollander, J. L. (1960). "Arthritis", 6th ed. Kimpton, London.

Leading Article (1960). Brit. med. F., 1, 865.

Lodge, T. (1956). Acta radiol. (Stockh.), 46, 435.

Mason, R. M., Murray, R. S., Oates, J. K., and Young, A. C. (1958). Brit. med. F., 1, 748.

Miller, L. F., and O'Neill, C. J. (1949). F. Bone Ft Surg., 31-A, 283.

Murray, R. S., Oates, J. K., and Young, A. C. (1958). F. Fac. Radiol. (Lond.), 9, 37.

Philipps, R. S. (1963). Paraplegia, 1, 116.

Reynolds, D. F., and Csonka, G. A. (1958). F. Fac. Radiol. (Lond.), 9, 44.

Romanus, R. (1953). Acta med. scand., Suppl. 280.

Stanworth, A., and Sharp, J. (1956). Ann. rheum. Dis., $15,140$.

Tribe, C. R. (1963). Paraplegia, 1, 19.

Trueta, J. (1964). "The Dynamics of Bone Circulation", in "Bone Biodynamics", ed. H. M. Frost, pp. 245-258 (Henry Ford Hospital International Symposium, 1963). Churchill, London.

Wright, V. (1963). Ann. rheum. Dis., 22, 77.

\section{L'arthritisme et l'infection génitale chez les paraplégiques \\ RÉsumé}

(1) 38 hommes atteints de paraplégie ont été étudiés avec soin. La paraplégie avait été causée par un traumatisme dans 33 cas. Elle était complète chez 24 et avait été présente pendant plus de deux ans chez 17 malades.

(2) La lésion de la moelle épinière était dans la région cervicale chez 4 malades, dans la région dorsale chez 18, dans la région dorso-lombaire chez 5 et dans la 
queue de cheval chez 11 . Des escarres de décubitus étaient présentes chez 25 malades et chez 12 d'entre eux étaient peu marquées. L'ulcération était en relation à la mobilisation différée et était trois fois plus fréquente chez ceux qui montraient des lésions sensorielles et motrices. Un oedème persistant était présent chez 11 malades. Des contractures en flexion étaient présentes chez 3 malades. 20 malades avaient maigri.

(3) Une infection urinaire était présente chez 25 malades et une infection génitale chronique chez 26; une cystoscopie avait révélé des calculs vesicaux chez 6 malades.

(4) Les doigts déformés noueux étaient le trait le plus saillant du changement dans les os et étaient présents chez 11 malades. Ils n'étaient pas présents chez les paraplégiques de moins d'un an; ils étaient présents plus fréquemment avec des escarres de décubitus et deux fois plus communs quand un oedème persistant était présent. Une ostéoporose prononcée des pieds avait été trouvée chez 23 malades, généralisée chez 8 et disseminée chez 15 malades. Une calcification du tissu conjonctif avait été vue chez 2 malades.

(5) Des changements dans l'articulation sacro-iliaque avaient été remarqués chez 12 malades. Ils étaient différents des changements dûs à une sacro-iliite qui sont remarqués chez les malades atteints de spondylite, de la maladie de Reiter et de la colite ulcereuse. Il est suggéré que dans les cas de paraplégie ces changements sont dûs aux stresses mécaniques sur les os ostéoporotiques formant l'articulation. Il n'y avait aucune évidence de corrélation entre les changements dans l'articulation sacro-iliaque et l'infection chronique génito-urinaire ou les escarres de décubitus. Les changements dans l'articulation sacro-iliaque étaient plus fréquents chez les malades dont l'admission à l'hôpital avait été différée, chez ceux qui avaient été gardés au lit pendant de longues périodes et aussi chez ceux où la mobilisation des membres avait été retardée.

(6) L'ostéoporose était présente chez les malades atteints de paraplégie de longue durée, chez ceux gardés au lit pendant de longues périodes et chez ceux dont les mouvements des chevilles avaient été très limités et chez ceux qui avaient un oedème persistant et des doigts déformés noueux.

(7) Les faits obtenus de cette étude suggèrent que l'ostéoporose, l'oedème persistant et les doigts déformés noueux des malades atteints de paraplégie peuvent tous être causés par des anomalies vasculaires. 